EESTI NSV TEADUSTE AKADEEMIA TOIMETISED 1955. IV kd., nr. 1 ИЗВЕСТИЯ АКАДЕМИИ НАУК ЭСТОНСКОИ ССР 1955. ТоМ IV, № 1

\title{
ARHEOLOOGILISED VÄLIUURIMISED EESTI NSV-S 1954. AASTAL
}

\section{O. SAADRE}

Eesti NSV Teaduste Akadeemia Ajaloo Instituut teostás 1954. aastal arheoloogilisi väliuurimisi 6 objektil. Kõigil kaevamistel koguti materjali kahe probleemi kohta, mille uurimise alal töötavad instituudi arheoloogid: 1) sugukondlik kord Eesti NSV territooriumil ja 2) ürgkogukondliku korra lagunemine ja klassiühiskonna tekkimine Eesti NSV territooriumil.

Esimese probleemi uurimise raamides teostati kaevamisi Narvas, Valma asulakohal Võrtsjärve loodekaldal „Kajaka” kolhoosi maa-alal, Iru linnamäel ja Kiviōli rajooni „Komsomoli” kolhoosis.

Materjali kogumiseks teise probleemi kohta jätkati kaevamisi Rõuge ja Otepää linnamäel.

Uldse kulutati nimetatud tööde läbiviimiseks 4041 tööpäeva.

Seoses Narva hüdroelektrijaama ehitustöödega tuli teostada kaevamisi Narvas, Narva jõe vasakul kaldal, ülalpool Hermanni kindlust, nn. „Lipovaja Jamkas", kust oli leitud kiviaegset ja hilisemat keraamikat. Kaevamiste teostamisel sai instituut tunduvat abi Narva Hüdroelektrijaama Ehitusvalitsuselt ja Narva Linna Ajaloo ja Arengu Muuseumilt. Kaevamisi juhatas instituudi teaduslik töötaja L. J a a $n$ i t s.

Kuigi kaevamised olid sondeerivat laadi ja seetõttu lühiajalised, koguti siin väärtuslikku materjali, peamiselt keraamikat, mille abil oli võimalik eristada kolme põhilist kultuurijärku. Ulemine, pinnalähedane kiht sisaldas peale hilisemast ajast pärineva materjali ka suurel hulgal XII-XIII sajandi keraamikat. See tõestab asula olemasolu siin juba enne saksa-taani vallutajate sissetungi Narva alale.

Sügavamatest kihtidest saadi neoliitilist keraamikat. Kultuurkihi kõrgem osa andis nn. tüüpilist kammkeraamikat (umbes III aastatuhandest e. m. a.), kuna sügavamal leiduv keraamika oli teiselaadiline. See oli palju primitiivsem, kuigi savinõud olid samuti laia suu ja ümara põhjaga nagu tüüpiline kammkeraamikagi. Leitud keraamika oli valmistatud teokarpide purruga segatud savist, nõrgalt põletatud ja vähe või peaaegu üldse mitte ilustatud. Sellelaadset keraamikat oli seni leitud ainult kiviajast pärinevas Akali asulas Emajōe suudmealal ja Riigikülas, Narva jõe alamjooksul. Viimases leiukohas polnud aga kultuurkihi stratigraafia küllalt selge. Narva linna asulakoht oma kindla stratigraafia najal kinnitab L. Jaanitsa poolt püstitatud hilisneoliitilise keraamika kronoloogiat 1 .

1 Vt. L. J a a n its, Neoliitilised ja varase metalliaja asulad Emajōe suudmealal. Eesti NSV Teaduste Akadeemia Toimetised, 1954, nr. 3, 1k. 355-356. 
Veel sügavamal avastas L. Jaanits kihi, mis võiks pärineda Siivertsi ja Kunda leiukohtadega samaaegsest asulast (V aastatuhandest e. m. a.).

L. Jaanits jätkas 1954. aasta suvel kaevamisi kiviajast pärineval Valma asulakohal ja jõudis peaaegu lõpule selle umbes $1000 \mathrm{~m}^{2}$ suuruse asulakoha kaevamisega. Kaevamistel ei läinud korda avastada elamute jälgi, kuid leiti leeasemeid. Nähtavasti on siin elatud lattidest ja okstest ehitatud ning mätastega, võib-olla ka loomanahkadega kaetud kergetes maapealsetes püstkodades, mis kergesti hävisid. Leeasemeist olid mõ̃ned sügavamale liiva sisse ulatuvad ja täidetud nõgise mullaga. Tõenäoliselt kasutati neid koldeid tule alalhoidmiseks, sest tule saamine oli tolleaegsetes primitiivsetes oludes väga raske. Leiumaterjal koosnes nagu eelmistel kaevamistelgi peamiselt tüüpilisest kammkeraamikast, tulekivist kõõvitsa-

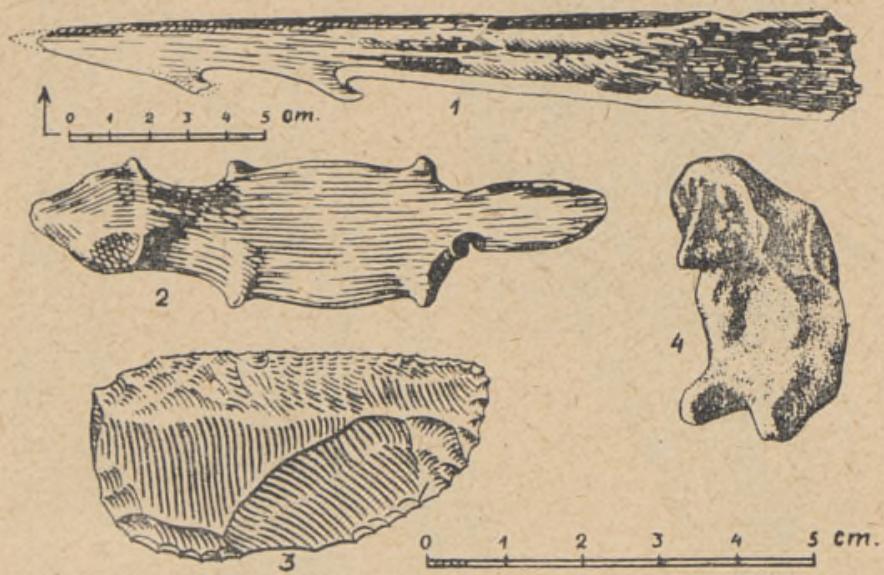

Joon. 1. Leide Valma asulakohalt: $I$ - luust ahinguots; 2 - kopra- või saarmakujuline luust ripats; 3 - tulekivist kōōvits; 4 - pōletatud savist looma vōi inimese kujuke.

test, nugadest, kivist talvakestest jne. Tähelepanu väärivad luust ahinguots ja põletatud savist looma (pruụnkaru?) või inimese kujuke (joon. 1, $1,4)$.

Asula äärel avastati samasse ajajärku kuuluvad mehe ja noore naise hauad. Surnute matmine asula maa-alale on vana komme, mis on seoses primitiivsete usuliste kujutelmadega. Nende matuste avastamine annab väärtuslikku lisa vastava ajajärgu kasinale antropoloogilisele leiumaterjalile. Surnute luukered olid seliliasendis ja kaetud õhukese liivakihiga. Mehe pea alt leiti kaks luust loomakujukest, mida oli kantud ripatsitena, sest neisse olid puuritud augukesed, nähtavasti nööri läbiajamiseks. Neist üks (joon. 1, 2) on meisterlikult voolitud ja kujutab edasiliikuvat veelooma - kobrast või saarmat. Naise pea juures oli samalaadne merivaigust kujuke.

Mehe luustik, nagu näitas selle antropoloogiline uurimine, omas ilmseid mongoloiidseid jooni.

Ajaloosektori juhataja A. V a s s a teostas uurimisi Iru linnamäel, jätkates 1953. aastal alustatud ala kaevamist ja laiendas seda kagu suunas. Kaevamised andsid uusi väärtuslikke leide, eriti vanima asustuse kohta.

Vanimas (I aastatuhande keskpaik e. m. a.) kultuurkihis avastati esmakordselt Eestis suurperele kuulunud elamu jäänused. Elamu oli piklik, asetses loode-kagu suunas ja tema põhi oli süvendatud liiva sisse. Elamu 
põranda laius oli $5 \mathrm{~m}$, kuna pikkus võis ulatuda 10 meetrini. Põranda keskel avastati mõned postide maasse kiilumise kivid. Postidele toetus tõenäoliselt viilukujuline katus.

Keset elamut leidus kolde ase, mille ümbruses oli palju loomaluid, suurema savinõu tükke ning muid esemeid. Selle järgi võib saada ettekujutuse seal elanud suurpere eluviisist ja majanduse laadist. Peamiseks tegevusalaks on olnud karjakasvatus, mille kõrval on tegeldud jahipidami-

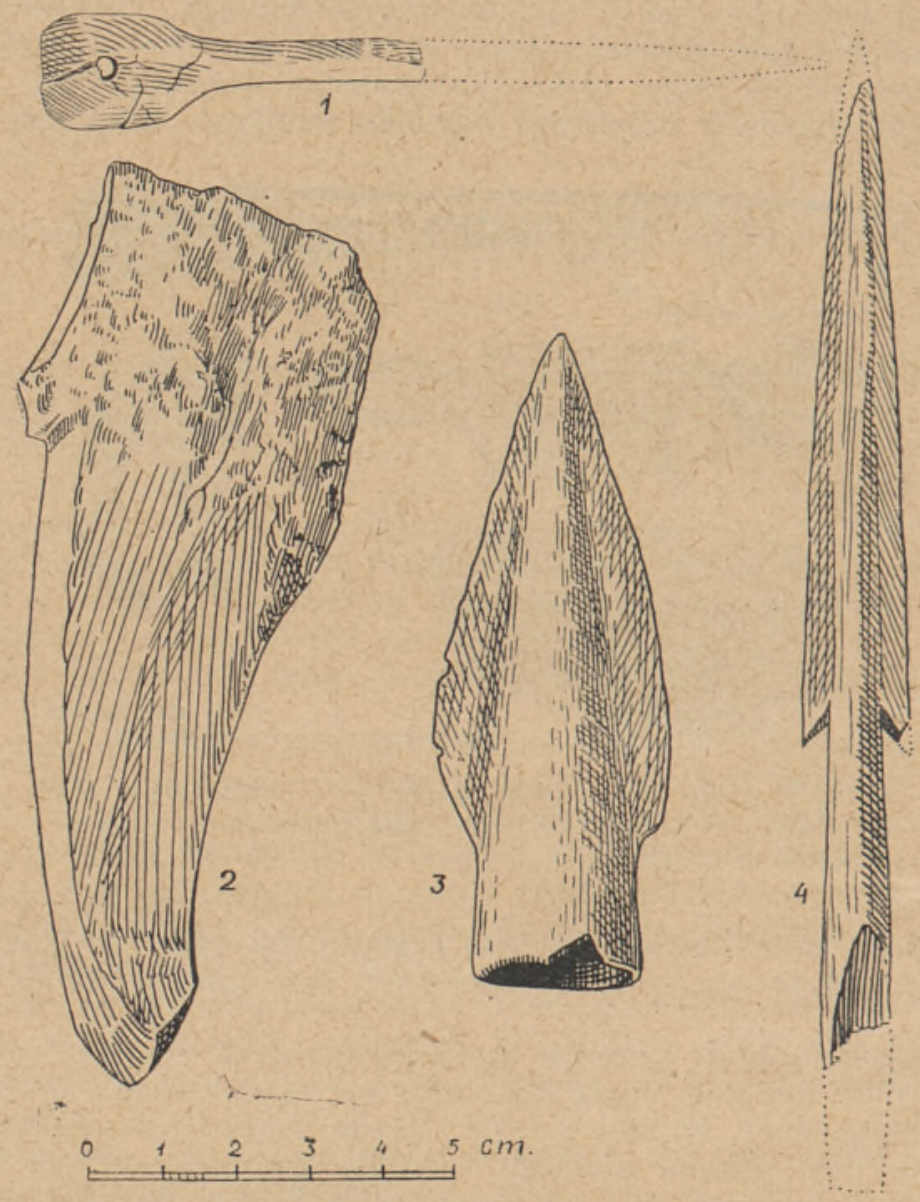

Joon. 2. $I$ - Labidakujulise peaga luust nōel kivikangrust Kiviōli rajooni „Komsomoli” kolhoosi maa-alalt. Leide Iru linnuselt: 2 - sarvest kõblas; 3 - pronksist odaots; 4 - luust nooleots.

sega (leiti hästi voolitud nooleots, joon. 2, 4), kalapüügiga ja ka maaviljelusega. Viimasest annavad tunnistust põdrasarvest valmistatud kõblas (joon. $2,2)$ ja kivist viljajahvatamise munakad.

Mitmesugusest käsitööst, muuseas ka pronksivalamisest on tôendeid saadud juba varasematel kaevamistel. 1954. aastal teostatud kaevamistel leiti pronksist naaskel, ehte tükk ja odaots (joon. 2,3 ), mị kõik on tõenäoliselt kohalikud tooted.

Kaevandi ülemisest kihist leiti puust ja kivist kindlustuste jäänuseid ja leeasemeid. Selles kihis leidus hulgaliselt käsitsivalmistatud keraamikat, rauast õmblusnõel, õngekonks, ihumiskive ja muid esemeid, mis kuuluvad 
$\mathrm{V}$-VIII sajandisse meie ajaarvamise järgi. Peale selle leidus kultuurkihis šlaki ja limoniidi tükke, mis näitavad, et siin on tegeldud ka rauasulatamise ja sepatöödega.

Kiviõli rajooni Lüganuse külanõukogu „,Komsomoli” kolhoosis oli üks riikliku kaitse alla võetud kivikangur jäänud ette kolhoosi ehitustegevusele. Vastavalt kultuurimälestusmärkide kaitse määrusele teostas Ajaloo Instituut kolhoosi šeffide poolt antud tööjõuga selle kivikangru osalist kaevamist. Nagu kaevamisel selgus, kuulus see kivikangur I aastatuhande teise poolde enne meie ajaarvamist. Siin oli hästi säilinud paeplaatidest laotud

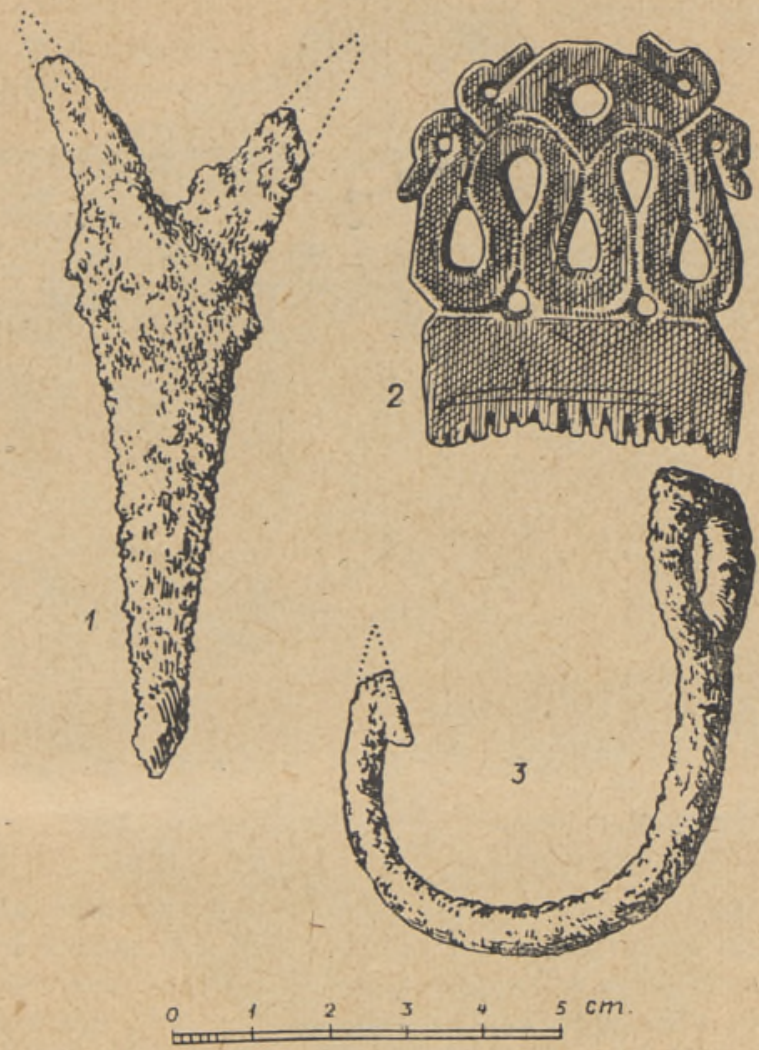

Joon. 3. Leide Rōuge linnamäelt: $I$ - rauast viskodaots; 2 - luust kammitaoline ripats; 3 - rauast ōngekonks.

kahekordne ringmüür, mille keskel oli paeplaatidest kirst. Selline ringmüür avastati Kirde-Eestis esmakordselt. Kivikirstus oli kõdunenud inim. luid ja sealt leiti 2 sellele ajale tüüpilist labidakujulise peaga ehtenõela (joon. 2, 1).

Instituudi vanem teaduslik töötaja $M . \mathrm{S} \mathrm{ch} \mathrm{m} \mathrm{i} \mathrm{e} \mathrm{d} \mathrm{e} \mathrm{h} \mathrm{e} 1 \mathrm{~m}$ jätkas 1954 . aastal Rõuge linnuse platoo kaevamist ja alustas 1953. aastal idapoolse valli taga põllul avastatud asulakoha uurimist.

Nảgu 1953. aastalgi, leiti ka nüüd pinnases savipõrandate jäänuseid ja leeasemeid, millest mõ̃ned kujutasid endast lehtrikujuliselt liiva sisse kaevatud auke, mis olid täidetud süte, nõgise mulla ja tules rabedaks muutunud kividega. Esemeist oli endiselt ülekaalus juba varem kirjeldatud keraamika ${ }^{2}$, millest leiti ligikaudu 10000 kildu. Leiti rauaräbu, pronksesemete

2 Vt. Eesti NSV Teaduste Akadeemia Toimetised, 1953, nr. 1, Ik. 63. 
valamisel kasutatud tiiglite katkendeid, hulk luiske, värtnaketri, luust ja rauast naaskleid, viskodaots (joon. 3, 1), onngekonks (joon. 3, 3) jm. Linnusest leiti loomaluid ja töötlemise jälgedega sarvi, samuti valmis esemeid: luust uisk, mõned naasklid, kunstipäraselt välja töötatud, stiliseeritud veelindu kujutava ornamendiga kammitaoline luust ripats (joon. 3 , 2). Linnuse kultuurkihist leiti araabia münte, nende katkendeid jm. Kõik need leiud tõendavad inimeste pidevat elamist linnuses ja annavad pildi nende koduse käsitöö arengust.

Linnuse pinnast on läbi kaevamata veel umbes $250 \mathrm{~m}^{2}$. Kaevamine loodetakse löpetada 1955. aastal. Seega oleks Rõuge linnus esimene täielikult läbi uuritud linnamägi Eestis.

Linnuse valli tagune asulakoht osutus ligikaudu 0,75 ha suuruseks, nagu seda oli võimalik kindlaks teha mullaproovide võtmisega. Sellest

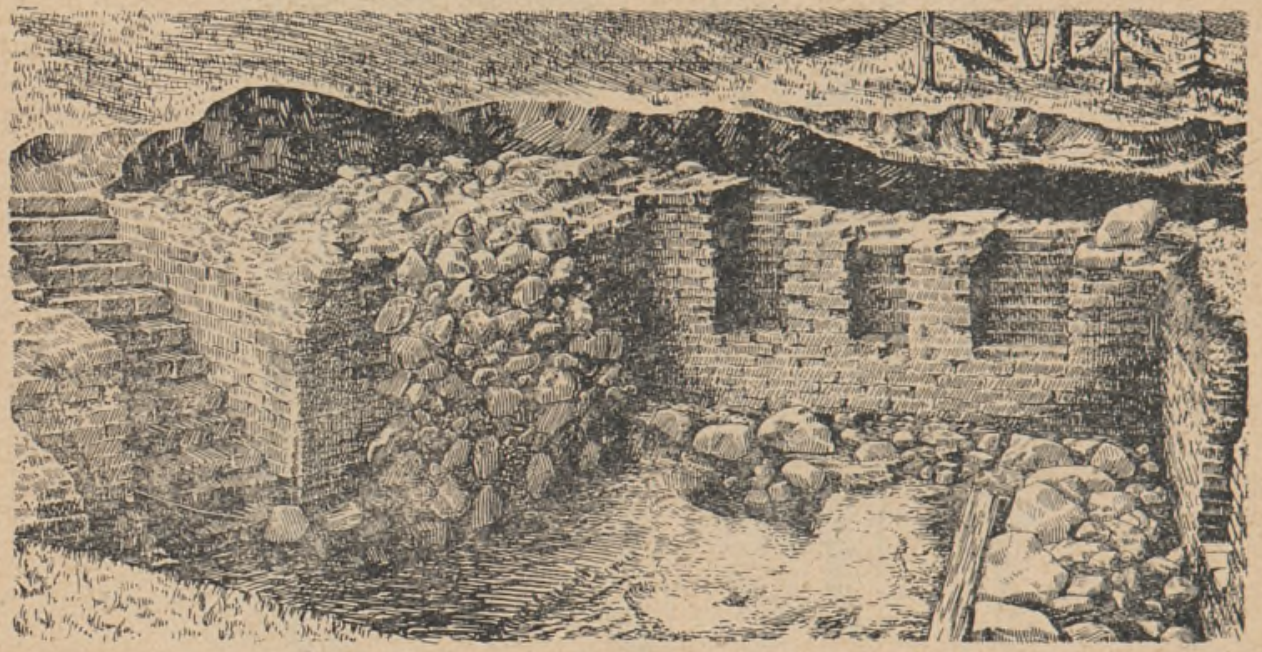

Joon. 4. Vaade Otepää linnamäel lahti kaevatud piiskopilossi „relvakambrile”.

jôti läbi kaevata $100 \mathrm{~m}^{2}$. Kaevamistel avastati künnikihi all ühe suurema hoone savipõrand ja paar leeaset. Samuti leiti siit suurel hulgal keraamikat, mis sarnanes linnuse keraamikaga. Ka teised esemed, nagu tiiglite katkendid, noad, värtnakedrad, luisud jm., osutusid väga sarnasteks linnuselt leitud esemetega. Asulakohast leiti samasugune luust kammitaoline ripats nagu linnusestki. Pole kahtlust, et nii linnust kui ka asulakohta kasutati üheaegselt. Võib arvata, et VI-IX sajandil, mil järjest tugevnesid eraomanduslikud suhted ja toimus varanduslik diferentseerumine ning üksikute jõukate perede esilekerkimine, kuulus linnus mõnele jõukale perele; hädaohu korral leidis siin varju ka linnuse külje all oleva asula elanikkond.

Elanikkonna tihedatele kultuurilistele sidemetele idapoolsete slaavi hõimudega osutab rida leide, nende hulgas araabia mündid ja nii linnuses kui ka asulakohas leitud kammitaolised ripatsid, mille sarnaseid nii ornamendi kui ka töötlemisviisi poolest on leitud Kamno linnuses Pskovi lähedal ja Pskovis.

Otepää linnamäe uurimisel oli 1954. aastal peamine tähelepanu pööratud piiskopilossi arhitektuuri selgitamisele ning lossi varemeist leitavate keskaegse materjaalse kultuuri jäänuste tundmaõppimisele: Rööbiti sellega lõpetati linnusesse viiva teeosa uurimine, mida alustati 1953. aastal. Eellinnusel, mille pindala on üle $3000 \mathrm{~m}^{2}$, kaevati kolm $16 \mathrm{~m}^{2}$ suurust proovikaevandit, et selgitada eellinnuse kultuurkihi iseloomu. 
Nagu juba eelmistel aastatel teostatud kaevamistel selgus, on kivilinnuse vanimaks osaks ringmüür. Sellega üheaegselt on sissekäigust lõuna poole ehitatud suurem, ligemale $12 \mathrm{~m}$ pikkune hoone, mille tellistest laotud väliskülg kaevati lahti juba 1952. aastal. Rusude all oli säilinud selle hoone maapealne osa. Kaevati lahti üks ca $32 \mathrm{~m}^{2}$ suurune ruum, mis oma pinnalt oli korrapäratu nelinurk. Ruum oli akendeta; tema läänepoolsel küljel oli 3 nišši, millest äärmised olid astmetega; põhjapoolsel küljel oli üks nišš ning lōunapoolsel küljel trepp, mis viis teisele korrusele (prae-

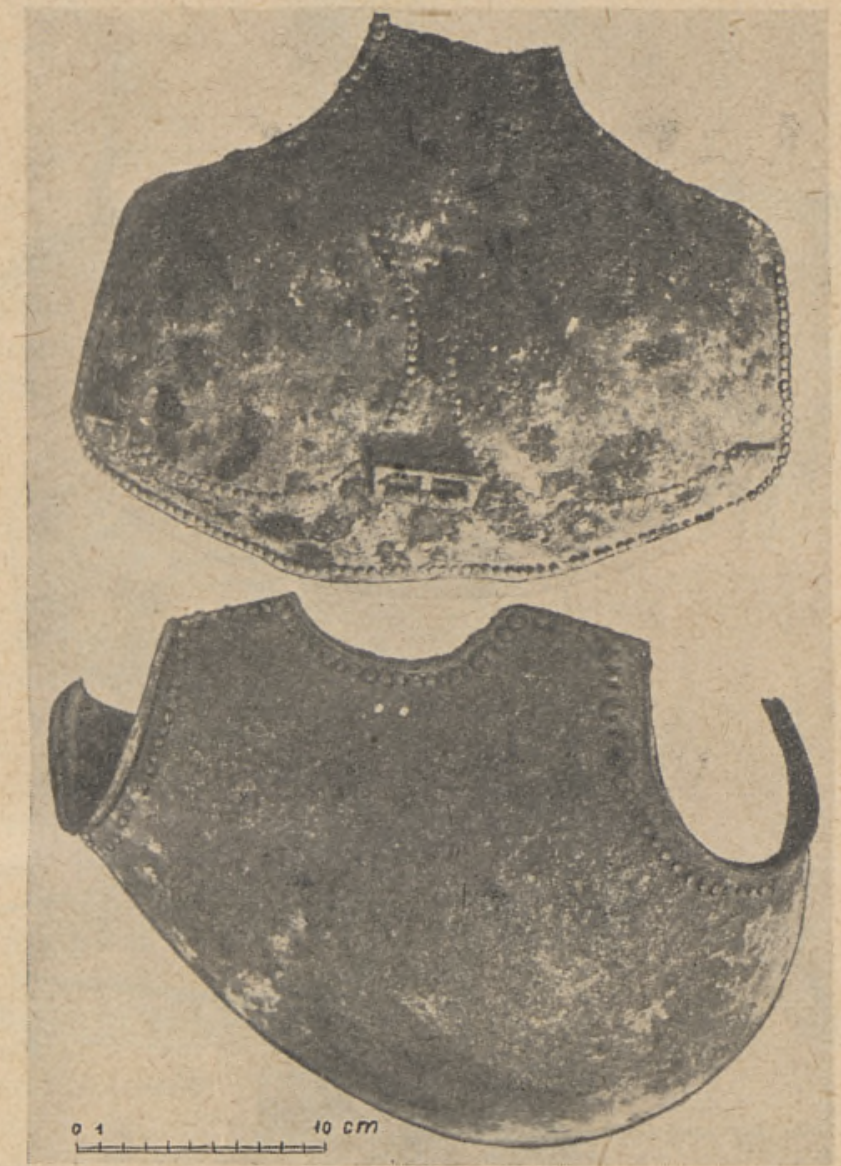

Joon. 5. Leide Otepää linnamäelt: raudrüü rinnakilp (ülal) ja seljakilp (all).

gusele maapinnale). Trepi astmetel olevate söestunud puu jälgede järgi võib otsustada, et astmed olid kaetud laudadega. Trepi alumise osa ees oli uks, mis avanes ruumi sisse. Uksest oli säilinud ainult hing, mis rippus konksu küljes (joon. 4). Ruum oli tõenäoliselt kasutusel relvakambrina. Siit leiti nelja raudrüü rinna- ja seljakilbid (joon. 5), nooleotsi, kivist tahutud kuule, rautatud kastide metallosi jm., mis kõik kandsid põlemise jälgi. Esemed kuuluvad XIV-XV sajandisse.

Linnuse ringmüüri põhjapoolse osa külge oli ehitatud suurem ruum, mille kontuurid paljastati 1954. aastal teostatud kaevamistel. Ehitusdetailide uurimine ja leidude analüüs näitab, et ruum on ehitatud XIII sajandil, 
kuid eespool kirjeldatud „relvakambrist” mōnevõrra hiljem. Ruumi mõōtmed olid $8 \times 16 \mathrm{~m}$; ruumi akendeks olid kolm põhjapoolses välismüüris olevat ambrasuuri, mis juba eelmistel aastatel lahti kaevati. Ruumi kagunurgas kaevati välja ligemale $12 \mathrm{~m}^{2}$ suurune neljakandiline massiivne tellistest laotud ehitis, mille ülemised osad on hävinud ja mis tõenäoliselt on olnud suur kerisega ahi. Nagu võib arvata läänepoolse välismüüri sees oleva süvendi ja selle taga oleva korstnajalataolise väljaehituse järgi, toimetati selle kütmist väljastpoolt hoonet. Ruumi sisepind kaevati lahti

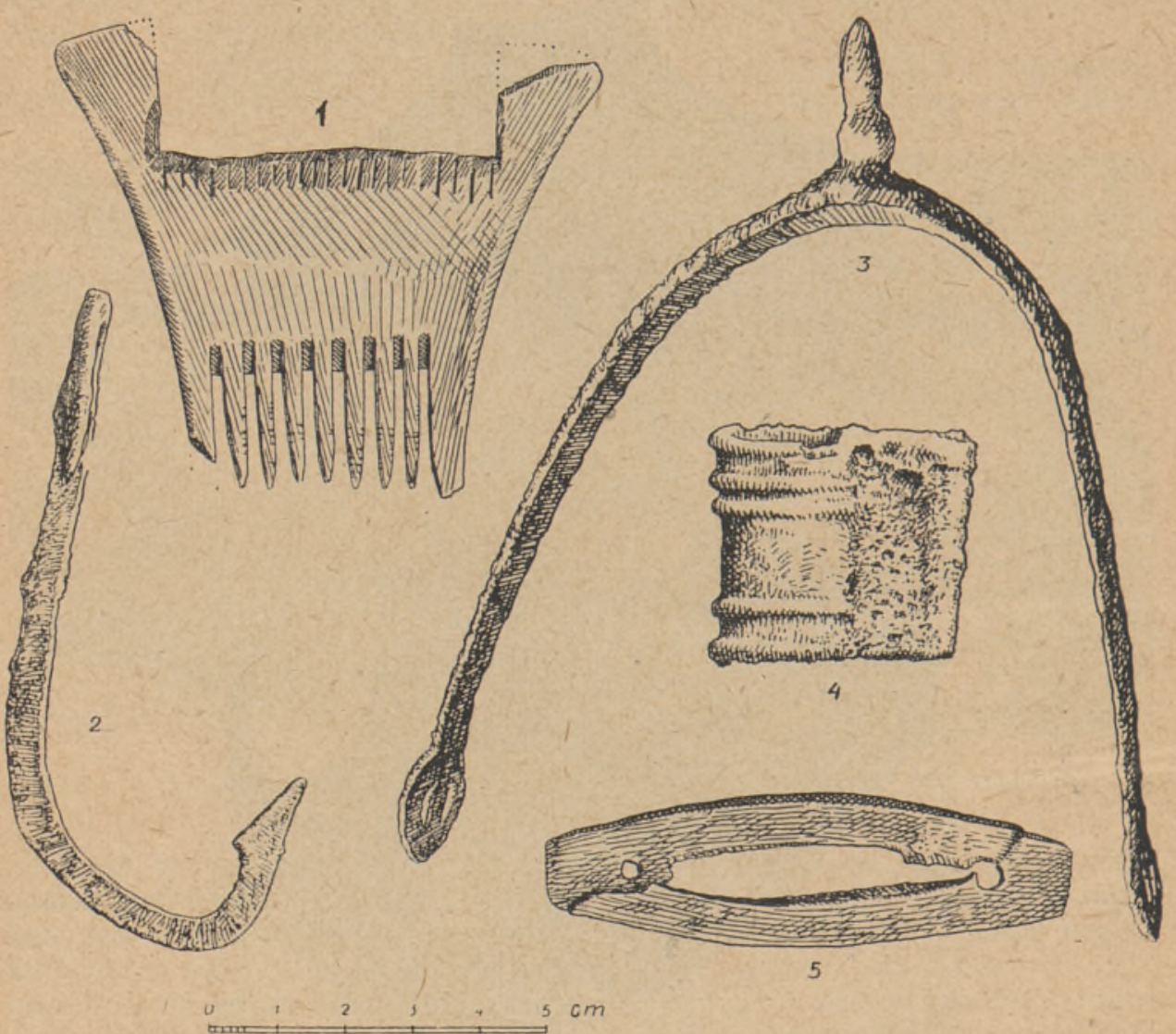

Joon. 6. Leide Otepää linnamäelt: 1 - luust kamm; 2 - rauast õngekonks; 3 - kannus; 4 - lukk; 5 - tuleraud.

ainult osaliselt. Edaspidine uurimine peaks tooma selgust selle ruumi otstarbe kohta, nagu ka kogu piiskopilossi ehituse kohta, millest meile pole säilinud mingit kirjeldust ega plaane. Varemed ise on olnud sajandeid mulla all ning seepärast on ajaloolises ja kunstiajaloolises kirjanduses selle lossi kohta siiani leidunud fantastilisi plaane ja oletusi. Teoksilolevad kaevamised on näidanud nende oletuste alusetust.

Mõlemast ruumist leiti peale relvastuse ka elutarbelisi esemeid, keraamikat ja muud. Oma enamikus olid need kohalikud tooted; leidusid ainult mõned üksikud läänepoolse päritoluga esemed, nagu ristilöödu kujutisega tinast naast ja mõned Reini alalt pärinevate savinõude killud.

Kultuurkiht läänepoolse müüri taga oli ligi 4 meetrit paks. Siit leiti palju eestlaste linnuse kasutamise ajajärku kuuluvaid elutarbelisi esemeid: 
keraamikat, mitmesuguseid eri raskusega värtnaketri, mis tõenäoliselt olid kasutusel erineva jämedusega lõnga ketramiseks, väikesi vöö küljes kantavaid luiske jm. Samast saadi ka rida slaavi päritoluga vibunoole otsi, kiievi tüüpi lukk (joon. 6, 4), kannuseid (joon. 6, 3), kamm (joon. 6, 1) jm.

Kaevandi lääneosas, umbes $3,5 \mathrm{~m}$ sügavusel, avastati müüri all leease, mille kivide vahed olid täidetud nõgise mullaga. Selle juures leiti Otepääle tüüpilist koredapinnalist keraamikat ning rauast õõskirves (joon. 7), mis pärinevad VI sajandist.

Eelmisel aastal läbi kaevamata jäänud tee sillutisealune osa kaevati nüüd läbi puutumata pinnani. Nagu juba eelmise aasta kaevamiste ülevaates märgitud $^{3}$, oli tee ehitatud XII sajandi lõpul või XIII sajandi algul, mida veelgi tõestas mitmesugune rikkalik leiumaterjal. Siit saadi ka põlenud viljateri. Eesti NSV Teaduste Akadeemia Taimekasvatuse Instituudis teostatud esialgse analüüsi andmeil olid need nisu-, odra- ja rukkiterad.

Sügavamal, peaaegu puutumata pinnases asuvast kultuurkihist saadi lisaks eelmise aasta leidudele veel primitiivset, tekstiilimustriga keraamikat, mis, nagu varem märgitud, kuulub I aastatuhande keskpaika e. m. a.

Linnuse platoo madalamasse ossa, põhjapoolse valli jalami lähedale kaevati 3 proovikaevandit. Kultuurki-

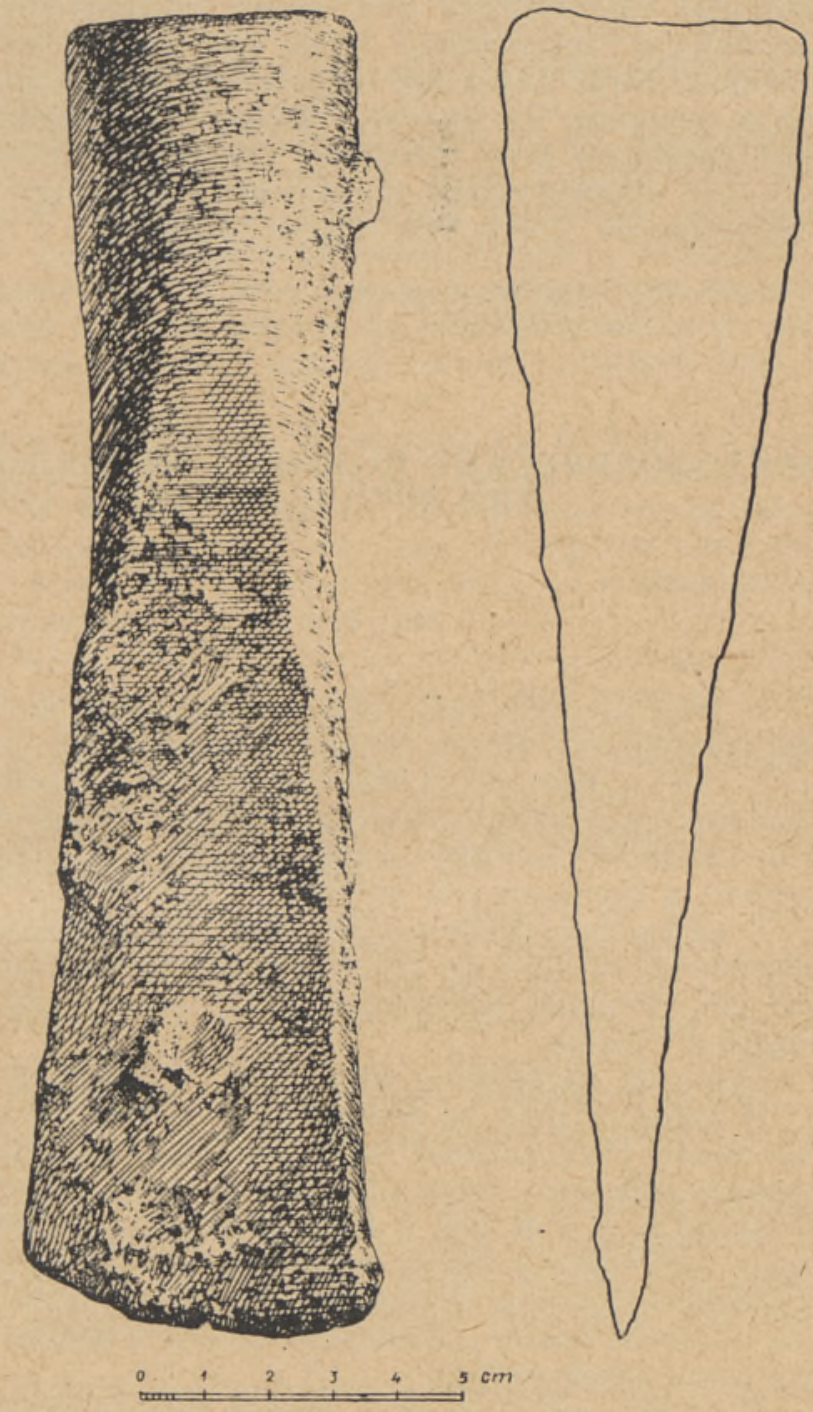
hi paksus oli linnuse

Joon. 7. Otepää linnamäelt leitud ōōskirves.

selles osas keskmiselt $160 \mathrm{~cm}$. Kahes kaevandis leidusid leeasemed; ühes neist kaevati välja $1,77 \times 2,1$ meetri suurune ovaalne musta mulla laik, mille äärtel oli muld tugevasti nõe- ja söesegune. Teine söesegune viirg ümbritseb laiku kaugerhalt. Tõenäoliselt on see laik püstkoja põhi.

Proovikaevandi sügavamast kihist saadi kettal valmistatud keraamikat, kivist ja luust värtnaketri, suur õngekonks (joon. 6, 2) ja tuleraud (joon. 6,

3 Vt. Eesti NSV Teaduste Akadeemia Toimetised, 1954, nr. 3, 1k. 370. 
5), mis kōik kuuluvad XI-XIII sajandisse. Proovikaevanditest leiti mõningaid esemeid, mis pärinevad piiskopilinnuse ajast (raudkinda sõrme kate, mõni kild läänepoolset keraamikat); enamik esemeid aga oli kohaliku päritoluga.

Kokku võttes võib märkida, et Ajaloo Instituudi poolt 1954. aastal teostatud väliuurimised olid kõigiti tulemusrikkad. Neoliitilise keraamika kronoloogia täpsustamine, leiud, mis aitavad selgitada paleantropoloogia küsimusi, Kirde-Eestis uut tüüpi kalme ehituse avastamine, suurpere elamu aseme leidmine Iru linnuses, Rõuge asula uurimine ning Otepää kivilinnuse kaevamise uued tulemused vổimaldavad täielikumalt valgustada meie vanemat ajalugu. Need uurimistulemused ongi juba kasutamist leidnud kolmeköitelise „Eesti NSV ajaloo” I osas.

Eesti NSV Teadusie Akadeemia Ajaloo Instituut

Saabus toimetusse

19. I 1955

\section{АРХЕОЛОГИЧЕСКИЕ ПОЛЕВЫЕ ИССЛЕДОВАНИЯ НА ТЕРРИТО- РИИ ЭСТОНСКОЙ ССР В 1954 ГОДУ}

\section{О. В. СААДРЕ}

Резюме

В 1954 году Институт истории Академии наук Эстонской ССР произвел археологические раскопки на шести объектах.

В рамках изучения проблемы жРодовой строй на территории Әстонии» производились археологические раскопки в гор. Нарве, на стоянке Валма (Вильяндиский район), на городище Иру и на территории колхоза «Комсомол», в Кивиылиском районе.

С целью получения необходимого для исследования проблемы «Распад первобытно-общинного строя и зарождение классового общества на территории Әстонии» материала были продолжены раскопки на городищах Рыуге и Отепяа.

Всего на проведение этих работ был использован 4041 рабочий день.

В городе Нарве, на левом берегу р. Нарвы, в так называемой жЛиповой ямке», было вскрыто поселение каменного века. По своему характеру нижний слой этого поселения имел сходство с культурным слоем V тысячелетия до н. э. в Кунда и Сийвертси (вблизи Нарвы). В расположенном выше слое была найдена примитивная керамика, глиняное тесто которой содержало большое количество раковин; обжиг керамики был слабый, и она почти не имела орнамента. По своей форме - это круглодонная посуда с широкой шейкой.

Над-этим слоем залегал другой слой, содержащий типичную ямочногребенчатую керамику III тысячелетия до н. э.

Четкая стратиграфия находок керамики подтверждает правильность хронблогической схемы последовательноети разных типов поздненеолитической керамики, составленной Л. Ю. Янитсом в основном по материалам раскопок в Акали ${ }^{1}$.

Раскопки в Валма дали много ценного материала для изучения этого поселения охотников-рыболовов III тысячелетия до н. э. Была раскопана почти вся площадь стоянки. Обнаружены очаги, в которых, судя по гу-

1 Л. Ю. Я н и тс, Поселения эпохи неолита и раннего металла в районе устья реки Эмайыги, Известия Академин наук Эстонской ССР, № 3, 1954. 
стому слою пережженной земли, поддерживался огонь. Помимо керамики, найдены различные изделия из кремня и кости (рис. $1,1,3)$; была обнаружена глиняная фигурка, напоминающая бурого медведя (рис. 1,4$)$.

Там же, на краю поселения, были вскрыты два погребения - мужчины и молодой женщины. Как показало антропологическое изучение, череп мужчины имел резко выраженные признаки монголоидности. Под черепом мужчины были найдены две костяные фигурки выдры или бобра (рис. 1,2$)$, которые, очевидно, носились на шее, а под черепом женщины такая же фигурка из янтаря.

Раскопками городища Иру впервые в Эстонии были обнаружены остатки жилища середины I тысячелетия до н. э., находившиеся в нижнем горизонте культурного слоя. Жилище представляло собой продолговатую полуземлянку с очагами. Вблизй очагов обнаружено много керамики и других предметов. Недалеко от жилища найден бронзовый наконечник копья, по всей вероятности местной работы. Большой интерес представляют также наконечник стрелы из кости и мотыга из оленьего рога (рис. 2 , $2,3,4)$.

На территории колхоза «Комсомол», Кивиылиского района, был частично вскрыт курган середины I тысячелетия н. э., сложенный из камней и земли. В этом кургане впервые на северо-востоке Әстонии обнаружены два концентрических круга из плитняка. В середине насыпи кургана находился каменный ящик с остатками скелета. Из находок упомянем две костяные булавки с лопатообразной головкой (рис. 2,1 ).

На городище Рыуге были обнаружены остатки глинобитных полов жилищ и очаги, врытые конусообразно в песок и заполненные углистой землей и обожженными камнями. Добытый на городище вещественный материал состоит главным образом из керамики (более 10000 черепков), но содержит также точила, пряслица, обломки тиглей, дротик и крючок (рис. $3,1,3)$. Особый интерес представляет костяная гребенчатая подвеска с фигурным ажурным орнаментом (рис. 3,2 ).

В Рыуге было начато также обследование поселения на напольной стороне восточного вала городища. Қак выяснилось, поселение занимало площадь примерно в 0,75 га. Материал из заложенного здесь раскопа сходен с материалом городища. В раскопе была найдена такая же гребенчатая подвеска, как и на городище, но меньшего размера. Эти подвески напоминают подобные находки с городища Камно, Псковской области, и из Пскова и указывают на существование связей между эстонскими и соседними славянскими племенами.

Раскопками 1954 года на городище Отепяа вскрыта часть помещений средневекового замка XIII-XV веков, построенного на городище после покорения эстонцев немецкими захватчиками (рис. 4). В развалинах замка были обнаружены предметы XIV - XV веков, в том числе части железных лат (рис. 5).

Среди находок X-XIII веков можно отметить железные шпоры, костяные гребни, замки киевского образца (рис. $6,1,3,4)$. В нижнем горизонте культурного слоя, под каменной стеной, был обнаружен очаг и около него втульчатый топор VI века (рис. 7).

В целях изучения культурного слоя нижнего плато городища были за-

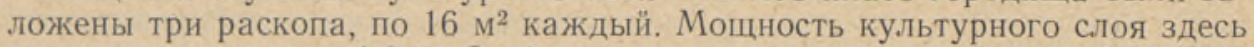
достигает в среднем 1,6 м. Слой содержал керамику и предметы XI-XIII веков, среди них рыболовный крючок и кресало (рис. $6,2,5$ ).

Результаты археологических исследований 1954 года и предыдущих лет учтены при составлении I тома трехтомной «Истории Эстонской ССР». 